УДК 330, 504.06

DOI: 10.17277/voprosy.2018.02.pp.079-085

\title{
A METHODOLOGY OF SOLVING PROBLEMS OF SUSTAINABLE DEVELOPMENT
}

\author{
N. S. Popov, O. V. Peshcherova, L. N. Chuksina \\ Tambov State Technical University, Tambov, Russia; \\ G. R. Derzhavin Tambov State University, Tambov, Russia \\ Reviewed by Doctor of Technical Science, Professor V. N. Shamkin
}

Keywords: sustainable development; methodology; scientific schools; nature-industrial systems; V. I. Vernadsky; diagnostic of stability; co-evolution.

\begin{abstract}
The problem of sustainable development of economy, nature and society has been in the center of attention of the governments of developed and developing countries since the early 1970s of the last century. Its solution depends on the results of the work of scientists specializing in a variety of fields of knowledge. There is a need to combine the accumulated knowledge on the co-evolution of nature and society as a whole - a methodology for sustainable development. In this article, we discuss the structure of the main information blocks of the methodology as an algorithm for solving various practical tasks.
\end{abstract}

In the last decades, the global scientific community has been developing the theory of sustainable development which fundamental provision will help find the answer to the question about the possibility of improving the welfare of people at the existing growth rates of the population in conditions of limited capacity of the environment and reduction of non-renewable stocks of natural resources. The humanity has no sufficient experience of the solution of so complex and versatile problem and therefore it is necessary to conduct its complex research for scientific justification of an optimum trajectory of growth of economic systems.

Definitions of sustainable development are well known. Table 1 indicates some alternative interpretations of the problem of sustainable development by different scientific schools.

Попов Николай Сергеевич - доктор технических наук, профессор кафедры «Природопользование и защита окружающей среды», e-mail: eco@nnn.tstu.ru; Пещерова Ольга Викторовна - ассистент кафедры «Природопользование и защита окружающей среды», ТамбГТУ, г. Тамбов, Россия; Чуксина Людмила Николаевна - кандидат педагогических наук, доцент кафедры зарубежной филологии и прикладной лингвистики, ФГБОУ ВО «Тамбовский государственный университет им. Г.Р. Державина», г. Тамбов, Россия.

УНИВЕРСИТЕТ им. В.И. ВЕРНАДСКОГО. №2(68). 2018. 
Academic schools on sustainable development

\begin{tabular}{|c|c|}
\hline Theory & Description of sustainable development \\
\hline $\begin{array}{l}\text { Equilibrium- } \\
\text { Neoclassical }\end{array}$ & $\begin{array}{l}\text { Welfare non-decreasing (anthropocentric); sustainable growth based } \\
\text { on technology and substitution; optimizing environmental externalities; } \\
\text { maintaining the aggregate stock of natural and economic capital; } \\
\text { individual objectives prevail over social goals; policy needed when } \\
\text { individual objectives conflict; long-run policy based on market solution }\end{array}$ \\
\hline $\begin{array}{l}\text { Neoaustrian- } \\
\text { Temporal }\end{array}$ & $\begin{array}{l}\text { Teleological sequence of conscious and goal-oriented adaption; } \\
\text { preventing irreversible patterns; maintaining organization level } \\
\text { (negentropy) in economic system; optimizing dynamic process of } \\
\text { extraction, production, consumption, recycling and waste treatment }\end{array}$ \\
\hline $\begin{array}{l}\text { Ecological- } \\
\text { Evolutionary }\end{array}$ & $\begin{array}{l}\text { Maintaining resilience of natural systems, allowing for fluctuation } \\
\text { and cycles (regular destruction); learning from uncertainty in natural } \\
\text { processes; no domination of foodchains by humans; fostering } \\
\text { genetic/biotic/ecosystem diversity; balanced nutrient flows in } \\
\text { ecosystems }\end{array}$ \\
\hline $\begin{array}{l}\text { Evolutionary- } \\
\text { Technological }\end{array}$ & $\begin{array}{l}\text { Maintaining co-evolutionary adaptable capacity in terms of } \\
\text { knowledge and technology to react to uncertainties; fostering economic } \\
\text { diversity of actors, sectors and technologies }\end{array}$ \\
\hline $\begin{array}{l}\text { Physical- } \\
\text { Economic }\end{array}$ & $\begin{array}{l}\text { Restrictions on materials and energy flows in/out the economy; } \\
\text { industrial metabolism based on materials - product chain policy: } \\
\text { integrated waste treatment, abatement, recycling, and product } \\
\text { development }\end{array}$ \\
\hline $\begin{array}{l}\text { Biophysical- } \\
\text { Energy }\end{array}$ & $\begin{array}{l}\text { A steady state with minimum materials and energy throughput; } \\
\text { maintaining physical and biological stocks, and biodiversity; transition } \\
\text { to energy systems with minimum pollutive effects }\end{array}$ \\
\hline $\begin{array}{l}\text { Systems- } \\
\text { Environmental }\end{array}$ & $\begin{array}{l}\text { Controlling direct and indirect human effects on ecosystems; balance } \\
\text { between material inputs and outputs to human systems; minimum stress } \\
\text { factors on ecosystems, both local and global }\end{array}$ \\
\hline $\begin{array}{l}\text { Environmental } \\
\text { Engineering }\end{array}$ & $\begin{array}{l}\text { Integration of human benefits and environmental quality and } \\
\text { functions by manipulation of ecosystems; design and improvement of } \\
\text { engineering solutions on the boundary of economics, technology and } \\
\text { ecosystems; utilizing resilience, self-organisation, self-regulation and } \\
\text { functions of natural systems for human purposes }\end{array}$ \\
\hline $\begin{array}{l}\text { Human } \\
\text { Environemntal }\end{array}$ & $\begin{array}{l}\text { Remain within the carrying capacity (logistic growth); limited scale } \\
\text { of economy and population; consumption oriented toward basic needs; } \\
\text { occupy a modest place in the ecosystem foodweb and the biosphere; } \\
\text { always consider multiple effects of human actions, in space and time }\end{array}$ \\
\hline $\begin{array}{l}\text { Socio- } \\
\text { Biological }\end{array}$ & $\begin{array}{l}\text { Maintain cultural and social system of interactions with ecosystems; } \\
\text { respect for nature integrated in culture; survival of group important }\end{array}$ \\
\hline $\begin{array}{l}\text { Historical- } \\
\text { Institutional }\end{array}$ & $\begin{array}{l}\text { Equal attention interests of nature, sectors and future generations; } \\
\text { integrating institutional arrangements for economic and environmental } \\
\text { policy; creating institutional long-run support for nature's interests; } \\
\text { holistic instead of partial solutions, based on a hierarchy of values }\end{array}$ \\
\hline $\begin{array}{l}\text { Ethical- } \\
\text { Utopian }\end{array}$ & $\begin{array}{l}\text { New individual value systems (respect for nature and future } \\
\text { generations, basic needs fulfillment) and new social objectives (steady } \\
\text { state); balance attention for efficiency, distribution and scale; strive for } \\
\text { small-scale activities and control of "side-effects" ("small is beautiful"); } \\
\text { long-run policy based on changing values and encouraging citizen } \\
\text { (altruistic) as opposed to individual(egoistic) behavior }\end{array}$ \\
\hline
\end{tabular}


Differences in scientific approaches to the analysis of the problem of sustainable development naturally give rise to certain contradictions in the assessment of ways to solve it, and on the other hand, create new opportunities for discussion and pluralism of opinions in the environmental economy [1].

Declaration "plea for pluralism" is justified for a number of reasons [2]:

- it is too early to limit the methodologies now;

- there is no best methodology in dealing with complex issues;

- multiple insights carry over a need for careful decision making on a policy level since it expresses that there is no single right solution;

- pluralism may help foster biological and cultural diversity;

- it may promote participation and decentralization.

The scientists should try to take a broad view encapsulating economic, social, ethical, historical, institutional, biological and physical elements [2].

In a consequence of multiplicity of the results received by different academic schools in the problem concerning sustainable development ripened need for the system organization of knowledge in the form of methodology doctrine about the principles, methods, forms and instruments of knowledge of regularities of process of a co-evolution of socio-economic and ecological systems. Existence of methodology significantly simplifies carrying out applied researches.

The methodology presented in work was formed at the same time both as "guide" and as "designer" for the solution of problems of modeling and management of processes of sustainable development and therefore is a part of more general system approach to a research of other global biosphere problems. Its features are connected with uniform approach to the analysis of processes of "industrial" and "natural" technology with the long-range planning in 20 and more years, a research of nature-industrial systems of various level of complexity and search "trade-off" options of their sustainable development.

The maintenance of methodology is organized in the form of a pyramidal algorithm from 8 information blocks: 1 - fundamental bases of a problem of sustainable development; 2 - system principles; 3 - characteristics of objects of a research from a position of their management; 4 - formalizations of problems of sustainable development; 5 - modeling of objects of a research; 6 simulation modeling of objects; 7 - diagnostics of stability of decisions; 8 practical recommendations of a case-study. Existence of feedback in blocks $2-7$ allows correcting the decisions made in the previous blocks.

Block 1 contains fundamental statements of Ch. Darwin's theory of "natural selection" and conclusions of the academician V. I. Vernadsky about evolution of the biosphere in a noosphere and resolutions of the international forums on sustainable development. V. I. Vernadsky's doctrine is a forerunner of the theory of sustainable development. In his works the deep interdependence of the geochemical and geophysical processes and processes generated by live matter is shown. Key provisions of the theory of evolution of the biosphere are formulated by the scientist in the form of the biogeochemical principles, the most important of which sounds as follows: "biogenous migration of atoms of chemical elements in the biosphere always tends to the maximum 
manifestation". In other words, live substance, having purposeful behavior, is always focused on the maximum consumption of material and energy resources that results in their deficiency, the competition of species, growth of waste and change of quality of the habitat. These circumstances become research objects in the theory of sustainable development. In the light of V. I. Vernadsky's doctrine of sustainable development, noospheric evolutionary process is represented as the basis for biogeochemical functions of live substance, dialectic laws of the nature and society and effective, stability of the process, the administrative decisions made in conditions of uncertainty voer the long period of time [3].

Block 2 contains the basic points, defining features of scientific approaches to the solution of sustainable development in the form of a number of the principles, for example, such as: "a complex research of a problem on expanded space states of system: economy - ecology - society" or "cyclic reproducibility of ecosystems conditions in space-time boarder". In Block 3 the concept Nature Industrial System as the uniform scientific platform for the solution of specific objectives of sustainable development is introduced and formalized. By the Nature-Industrial System (NIS) the set of objects of branches of the industrial (agrarian) sector and the objects of the environment forming united technical, economic and ecological structure of the considered region ordered interacting with each other in processes of exchange of information, consumption of material - energy resources and processing's of waste is called. The NIS represents a special class of open macro-bio-technological systems with hierarchical structure of the organization of elements, deterministic- stochastic nature of separate processes, nonlinear character of behavior and with delays in information and measuring channels [4].

Formalization of problems of sustainable development with a vector criterion are given in Block 4. These tasks designated as $A, B, C, \ldots, H$ also possess various degree of complexity, being static or dynamic, deterministic or stochastic. The optimal solution is made on a condition of performance of "critical" stability of the NIS. In Block 5 the problem of definition of the automated modeling of the NIS on the basis of the concept of the "ecological" reactor which base are achievements of the theory of the chemical reactor is formalized. The ecological reactor represents an open, self-regulating system formed of a biotope, biocenoses and natural power sources, intended for synthesis of species in the quantities and ratios determined by the conditions of her functioning which have developed on the long period of time. The eco-reactor is characterized by concrete existential borders, final number of contacts with the external environment, the known mechanisms of interaction of live organisms and chemicals and the known hydrodynamic structure of the material and power streams existing between required points of the entrances and exits. The concept of the ecological reactor is useful when modeling ecological subsystems [5]. Actions in Block 6 allow estimating the effectiveness of a control system of the NIS using the Monte Carlo method, or analytical methods, in case of use enough simple models (for example, the solution in mean square for the probabilistic differential equations). 
In Block 7, the methodology verification of solutions of the closed control system on the NIS stability is carried out. Depending on features of tasks of management various criteria of estimation and approaches known in the classical theory of stability for the deterministic and stochastic systems which are based on "internal" and "external" descriptions can be used here. In one of the examples, the criterion of "absolute" stability is used. In that case when the NIS stability is determined by the behavior of the indexes and indicators developed by various international organizations it is possible to use the concepts of convergence known in the theory of stochastic processes, such as convergence "in mean square", "in probability" and others [6]. Based on the results of assessment of stability of decisions practical recommendations (Block 8) are developed.

The methodology described in this study was applied to the solution of a problem of energy saving on wastewater treatment plant, to the development of technology of utilization of molasses bards (wastes from alcoholic production) at the biochemical plant, the organization of systems of monitoring in Severodonetsk (Ukraine) and Tambov (Russia) [7].

\section{Conclusion}

The methodology presented in the study is one of the attempts of the system organization of knowledge of the nature and the society aimed at finding solutions, contributing to the sustainable economic development. One of such decisions is related to the transformation of the "linear" economy to the "circular" one. In the long term, the solution of the problem of sustainable development has to be based on the principles of natural self-organization of socio-economic and ecological processes.

\section{Acknowledgments}

The study was presented for the first time at the 1st International Conference "Circular and Bioeconomy" (CIBEK 2018) organized by Belgrade School of Engineering Management Union "Nicola Tesla" University together with the Serbian Society for Engineering Management in Belgrade on April 19, 2018.

The authors of this article express gratitude to the leadership of School of Engineering Management and sponsors of the conference - to the Ministry of Environment Protection, the Agency of Energy Efficiency, Institute of Sustainable Development and the Serbian Commercial Chamber for financial support of participants in a conference.

\section{References}

1. Norgaard R.B. The case for methodological pluralism, Ecological Economics, 1989, vol. 1, pp. 37-57.

2. Van den Bergh J.C.J.M. Ecological Economics and Sustainable Development: Theory, Methods and Applications, Edward Elgar Publ. Lim. Cheltenham, UK, $1965,312 \mathrm{p}$. 
3. Popov N.S., Peshcherova O.V., Chuksin A.A. [Vernadsky, evolution and sustainable development], Voprosy sovremennoj nauki $i$ praktiki. Universitet im. V. I. Vernadskogo [Problems of Contemporary Science and Practice. Vernadsky University], 2017, no. 4(66), pp. 29-40. doi: 10.17277/voprosy.2017.04.pp.029-040 (In Russ., abstract in Eng.)

4. Popov N.S., B'yanko V., Lysenko I.O., Novakovski P., Chan Min' T'in', Chuksina L.N., Yakunina I.V. Povyshenie ehnergoehffektivnosti prirodo-promyshlennyh system [Increase of energy efficiency of natural-industrial systems], Tambov: Izdatel'stvo Pershina R.V., 2014, 146 p. (In Russ.)

5. Ermolaeva E.V., Zamaraeva G.N., Zemskova V.T., Luzgachev V.A., Panov Yu.T., Bobkova E.S., Rybkin V.V., Popov N.S., Chan Min' T'in'. Modelirovanie tekhnologicheskih i prirodnyh sistem: uchebnoe posobie [Modeling of technological and natural systems], Tambov: Izdatel'stvo Pershina R.V., 2014, 154 p. (In Russ.)

6. Popov N.S., Peshcherova O.V., Strel'nikova A.E. [On assessments of the sustainability of development processes in nature-industrial systems], Voprosy sovremennoj nauki i praktiki. Universitet im. V. I. Vernadskogo [Problems of Contemporary Science and Practice. Vernadsky University], 2017, no. 3(65), pp. 61-74 doi: 10.17277/voprosy.2017.03.pp.061-074 (In Russ., abstract in Eng.)

7. Popov N.S., Peshcherova O.V., Chan Min' T'in'. [Modeling the optimal air distribution in the corridor aeration tank], Voprosy sovremennoj nauki i praktiki. Universitet im. V. I. Vernadskogo [Problems of Contemporary Science and Practice. Vernadsky University], 2016, no. 1(59), pp. $19-28$ doi: 10.17277/voprosy. 2016.01.pp.019-028 (In Russ., abstract in Eng.)

\section{Список литературы}

1. Norgaard, R. B. The Case for Methodological Pluralism / R. B. Norgaard // Ecological Economics. - 1989. - Vol. 1. - P. 37 - 57.

2. Van den Bergh, J.C.J.M. Ecological Economics and Sustainable Development: Theory, Methods and Applications. - Edward Elgar Publ. Lim. Cheltenham, UK, 1965. $-312 \mathrm{p}$.

3. Попов, Н. С. Вернадский, эволюция и устойчивое развитие / Н. С. Попов, О. В. Пещерова, А. А. Чуксин // Вопр. соврем. науки и практики. Университет им. В. И. Вернадского. - 2017. - № 4(66). - С. 29 - 40. doi: 10.17277/voprosy. 2017.04.pp.029-040

4. Повышение энергоэффективности природо-промышленных систем : учеб. пособие / Н. С. Попов [и др.] ; под общ. ред. Н. С. Попова. - Тамбов : Изд-во Першина Р. В., 2014. - 146 с.

5. Моделирование технологических и природных систем : учеб. пособие / Е. В. Ермолаева [и др.] ; под общ. ред. Ю. Т. Панова и Н. С. Попова. - Тамбов : Изд-во Першина Р. В., 2014. - 154 с.

6. Попов, Н. С. Об оценках устойчивости процессов развития в природо-промышленных системах / Н. С. Попов, О. В. Пещерова, А. Э. Стрельникова // Вопр. соврем. науки и практики. Университет им. В. И. Вернадского. - 2017. - №3(65). C. 61 - 74. doi: 10.17277/voprosy.2017.03.pp.061-074

7. Попов, Н. С. Моделирование оптимального распределения воздуха в коридорном аэротенке / Н. С. Попов, О. В. Пещерова, Чан Минь Тьинь // Вопр. соврем. науки и практики. Университет им. В. И. Вернадского. - 2016. - №1(59). C. 19 - 28. doi: 10.17277/voprosy.2016.01.pp.019-028 


\section{Методология решения задач устойчивого развития}

\section{Н. С. Попов, О. В. Пещерова, Л. Н. Чуксина}

ФГБОУ ВО «Тамбовский государственный технический университет», г. Тамбов, Россия; ФГБОУ ВО «Тамбовский государственный университет имени Г.Р. Державина», 2. Тамбов, Россия

Ключевые слова: В. И. Вернадский; диагностика устойчивости; коэволюция; методология; научные школы; природо-промышленные системы; устойчивое развитие.

Аннотация: Проблема устойчивого развития экономики, природы и общества находится в центре внимания правительств развитых и развивающихся стран с начала $1970-x$ гг. Ее решение зависит от результатов работы ученых, специализирующихся в различных областях знаний. Необходимо объединить накопленные знания о коэволюции природы и общества в единое целое - методологию устойчивого развития. Рассмотрена структура основных информационных блоков методологии как алгоритма решения различных практических задач.

(C) Н. С. Попов, О. В. Пещерова, Л. Н. Чуксина, 2018 